\title{
Leucocytic DNA Damage of Racing and Retired Horses
}

\author{
Y. T. Szeto
}

\section{ABSTRACT}

Comet assay was performed on five racing horses (age, mean \pm SD: $4.4 \pm 0.5$ years old) and five retired horses $(10.2 \pm 4.1$ years old). DNA damage of whole blood samples were tested with or without UV irradiation. Three specimens were taken from each horse and one month apart for each specimen to test for reproducibility. Result showed that racing horses had statistically significant lower baseline and UV induced DNA damage in leucocytes than retired horses. Positive associations were also seen between age and baseline DNA damage or UV induced DNA damage from Spearman correlation analysis.

Keywords: Comet assay, DNA damage, Horses, Leucocytes, Oxidative stress.

Published Online: June 04, 2021

ISSN: 2684-5199

DOI: $10.24018 /$ ejbio.2021.2.3.204

\section{Y. T. Szeto*}

Department of Chemistry, Hong Kong

Baptist University, Hong Kong.

(e-mail: ytszeto@alumni.vtc.edu.hk)

*Corresponding Author

\section{INTRODUCTION}

Cellular DNA damage have been shown to correlate with aging in human is some studies [1]. This may be the resultant of decreased repairing capacity in aging process and the accumulated unrepaired DNA damage. Oxidative stress enhanced free radicals, overwhelming surrounding cellular DNA, and causing DNA damage. Human studies had shown the strong linkage between exercise and oxidant production, e.g. hydrogen peroxide [2). It has been shown that oxidative stress reduces the immune response in horses undergoing intensive training and led to impaired immunity [3]. This cellular damage caused by ROS (Reactive Oxygen Species) alters the structure and functionality of multiple tissues and cellular structure, which in turn, would affect their wound healing ability, ageing and lifespan [4].

ROS is a group of compounds with the ability to oxidise wide range of molecules. These compounds carry a free electron at outer orbital and are chemically unstable, such as hydroxyl radical (.OH), nitric oxide, and superoxide radical $\left(. \mathrm{O}_{2}^{-}\right)$. However, agents such as peroxynitrite (ONOO-), hydrogen peroxide $\left(\mathrm{H}_{2} \mathrm{O}_{2}\right)$, and hypochlorous acid are also oxidative while they do not process unpaired electron.

Cellular ROS production is an ongoing process by metabolic reactions in mitochondria. Some cells, such as neutrophils, use the endogenous ROS source as a weapon to defeat foreign pathogens. However, the damage is not specific. Macromolecules, such as lipids, proteins, and DNA, are vulnerable to ROS oxidation. Different forms of oxidative damage are seen in DNA molecule, such as disincorporation, single, or multiple breakings in DNA chains [5].

Training and racing are the activities to generate free radicals and ROS in equine [6]. It has been shown oxidative stress could be provoked after strenuous exercise and create an overwhelming internal ROS environment. Oxygen consumption during exercise could increase up to 7 folds in equine [7]. Free radical spikes in exercise have been demonstrated [8]. However, conflicting results are there. Results also suggest that the defence mechanism of horses against ROS works effectively during prolonged exercise. No increase in ROS during or after exercise has been observed [9]. Nevertheless, prolonged physical exercise with moderate intensity shows evidence to increase the lifespan of animals such as mice and also in humans. It would be of interest to see the resultant DNA damage of horses between racing (younger) and retired (older) stages.

In this study, DNA damage of leucocytes of horses at different ages were investigated. DNA damage of peripheral white blood cells would be tested by comet assay to evaluate the baseline and UV induced damages.

\section{MATERIALS AND METHODS}

Whole blood samples from 5 racing and 5 retired horses were taken. The ages of racing horses are 4, 4, 4, 5 and 5 years old at the beginning of study. While the ages of retired group were $6,8,8,13$ and 16 years old. One $\mathrm{mL}$ peripheral blood sample left over from routine checkup was kept for each horse. The blood sample were kept again after one and two months. $\mathrm{K}_{2}$ EDTA blood samples were immediately stored at $-80{ }^{\circ} \mathrm{C}$ freezer within 10 mins of sampling without any cryopreservative. EDTA blood samples were defrosted in a water bath at $37^{\circ} \mathrm{C}$ when used.

Comet assay was performed to investigate the DNA damage in this study. The clean microscopic slides were coated with $1 \%$ agarose gel in deionised water and air dried for use. Fifteen $\mu \mathrm{L}$ of blood sample was mixed with $340 \mu \mathrm{L}$ $1 \%$ low gelling agarose (in PBS, pH 7.4) (Sigma, St Louis MO, US) in a microtube. Eighty-five $\mu \mathrm{L}$ of mixture was applied the coated slides and immediately covered with $22 \times 22 \mathrm{~mm}$ coverslip. A slide could accommodate 2 gels and 2 slides (i.e., total 4 gels) were prepared for each specimen. The slides were then placed into a refrigerator at $4{ }^{\circ} \mathrm{C}$ for $10 \mathrm{~min}$. Once the gels were solidified, the coverslips were 
removed with extra caution to avoid damaging the gel. One slide from each specimen was exposed under UV light for oxidative stress investigation while the other slide was for baseline DNA damage detection.

Irradiation on samples was achieved by UVB (280-315 $\mathrm{nm}$ ) lamp at the distance of $6 \mathrm{~cm}$ for $1 \mathrm{~min}$. UV treated and un-treated slides were then submerged into a lysis solution (2.5 M NaCl, 0.1 M EDTA, 1\% Triton X-100, 10\% DMSO, $\mathrm{pH} 10)$ at $4{ }^{\circ} \mathrm{C}$ for 1 hour. Slides were further transferred to the electrophoresis solution $(0.3 \mathrm{M} \mathrm{NaOH}, 0.1 \mathrm{mM}$ EDTA, $\mathrm{pH}>13$ ) for 10 minutes for 2 changes for alkaline treatment and to remove excess lysis solution prior to electrophoresis. Finally, slides were put on the platform of the electrophoresis tank and covered with electrophoresis solution. Electrophoresis was run for $15 \mathrm{~min}$ and constant voltage $25 \mathrm{~V}$ was applied. The initial current was set to $300 \mathrm{~mA}$ by adjusting the volume of electrophoresis solution in the tank. After electrophoresis, the slides were submerged in tap water for three 5-minute cycles to remove alkaline solution. Finally, the samples were stained by using $50 \%$ Giemsa stain, prepared with equal amount volume of filtered Giemsa solution (AppliChem, GmbH, Darmstadt, Germany) and $\mathrm{pH}$ 6.8 buffer for 45 minutes. The slides were rinsed under tap water, mounted and DNA damage of leucocytes were visually scored at 200x under microscope (Nikon Eclipse 80I). Fifty cells were counted for each gel. Each DNA damage grading was given a value and divided from 0 (Intact) and 4 (maximum damage with nearly all DNA at the tail region). The score was calculated by applying the following formula: (number of cells DNA was damaged grade $0 \times 0)+($ number of cells in DNA damage grade $1 \times 1)+($ number of cells in DNA damage grade $2 \times 2)+($ number of cells in DNA damage grade $3 \times 3)+($ number of cells in DNA damage $4 \times 4)$. As a result, the score of each gel should be in the range of 0 to 200 .

Mann Whitney test was used to compare DNA score of between racing and retired groups for both baseline and UV induced DNA damage, $P$ value less than 0.05 was considered statistically significant. Association of between DNA baseline or UV induced damage with age were also tested by Spearman correlation.

\section{RESUlTS}

Two out of three trials (first and third month) indicated leucocytes of retired horses had higher baseline DNA damage than racing horses. The second trial showed higher level of damage but did not reach statistically significant level (Fig. 1, Table I). While retired horses had higher UV-induced DNA damage in all three trials. Similar results obtained in correlation study. Significant correlation between baseline DNA damage and age in two out of three trials and all trials showed significant correlation in UV-induced experiments (Fig. 2).

TABLE I: DNA SCORE OF RACING AND RETIRED HORSES AT BASELINE AND UV-INDUCED LEVELS

\begin{tabular}{ccccccc}
\hline & \multicolumn{2}{c}{$1^{\text {st }}$ month } & \multicolumn{2}{c}{$2^{\text {nd }}$ month } & \multicolumn{2}{c}{$3^{\text {rd }}$ month } \\
\hline & Racing & Retired & Racing & Retired & Racing & Retired \\
\hline Baseline & $33.6 \pm$ & 64.4 & $45.6 \pm$ & $58.6 \pm$ & $35.6 \pm$ & $72.4 \pm$ \\
$\begin{array}{c}\text { DNA score, } \\
\text { mean } \pm \text { SD }\end{array}$ & 8.6 & \pm 11.9 & 8.7 & 12.1 & 13.4 & 11.9 \\
UV induced & $60.8 \pm$ & $129.0 \pm$ & $68.2 \pm$ & $98.8 \pm$ & $53.4 \pm$ & $105.2 \pm$ \\
$\begin{array}{c}\text { DNA score, } \\
\text { mean } \pm \text { SD }\end{array}$ & 9.0 & 24.5 & 16.6 & 14.9 & 13.2 & 11.6 \\
\hline \hline
\end{tabular}

Three Individual Trials Performed. ALL showed statistically significant difference between horses at different age except underlined scores $\left(2^{\text {nd }}\right.$ month trial).

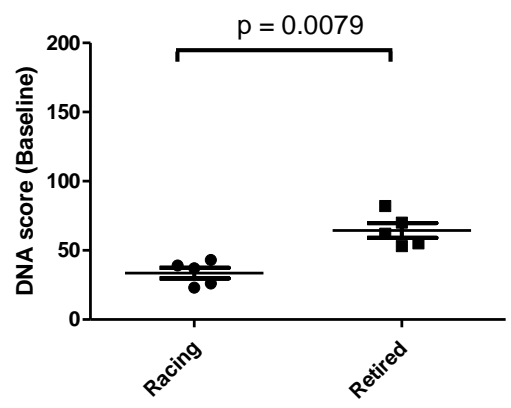

a)

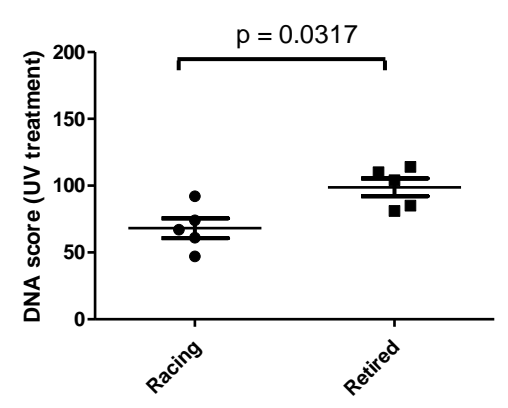

d)

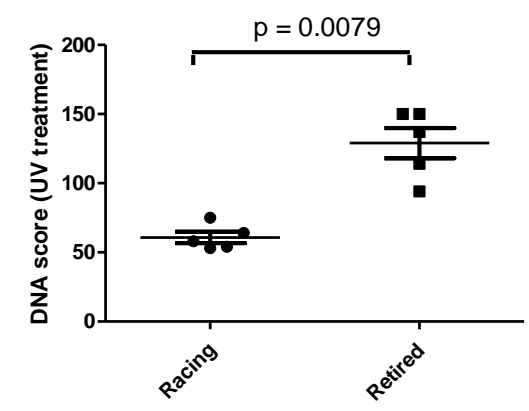

b)

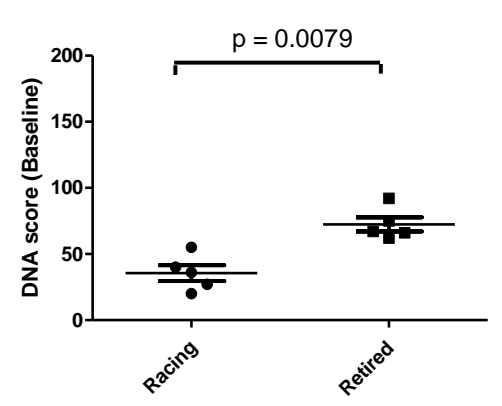

e)

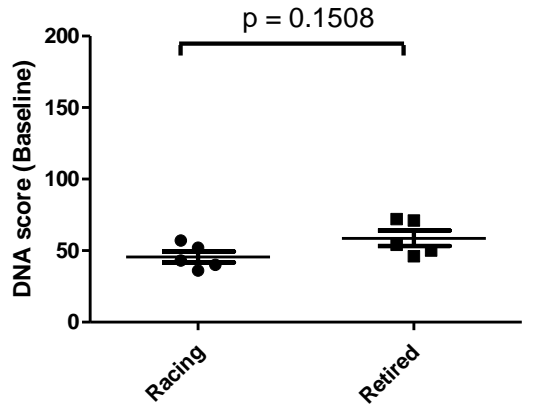

c)

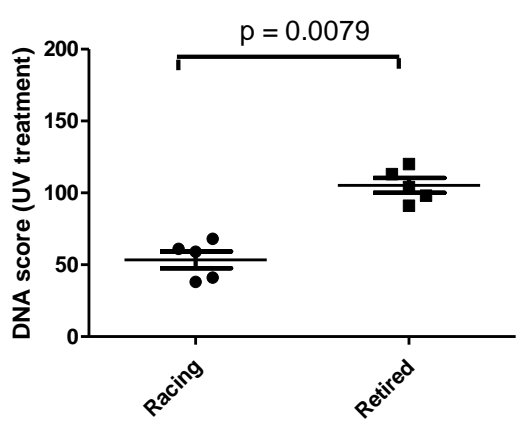

f)

Fig. 1. Baseline (a, c, e) and UV-induced (b, d, f) DNA damage (arbitrary score) of leucocytes of racing and retired horses. 1a \& b) first month trial; $1 \mathrm{c} \&$ d) second month trial and 1 e \& f) third month trial. Unpaired t- test with $P<0.05$ was considered as statistically significant. 


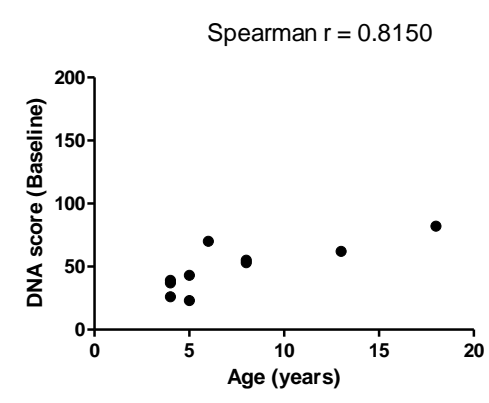

a)

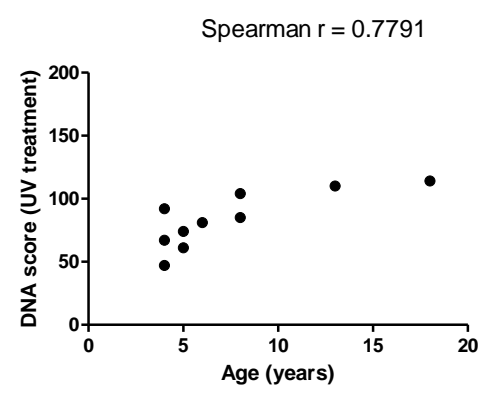

d)

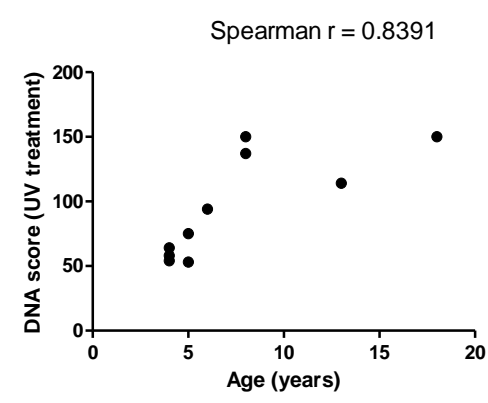

b)

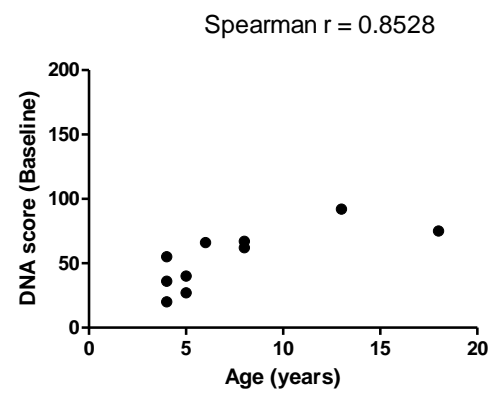

e)

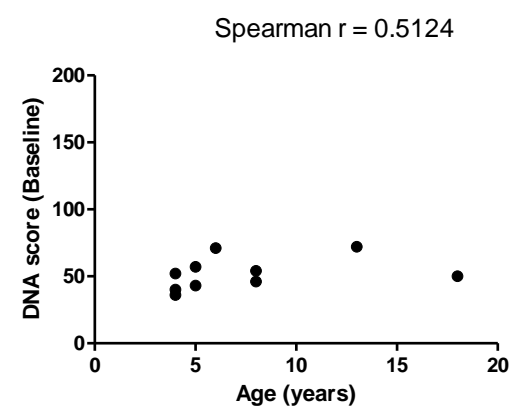

c)

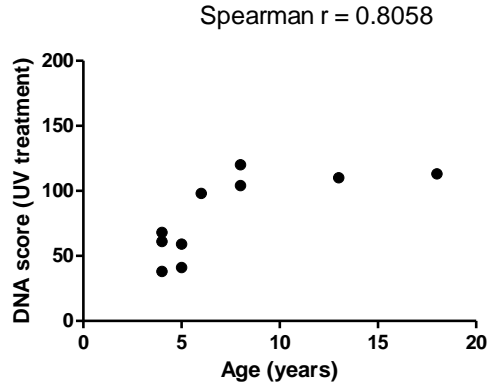

f)

Fig. 2. Correlation between DNA damage and age of horse. Baseline (a, c, e) and UV-induced (b, d, f) DNA damage (arbitrary score) of leucocytes. 1a \& b) first month trial; 1 c \& d) second month trial and 1 e \& f) third month trial. Spearmen correlation. All showed statistically significant correlation except baseline DNA damage in second month trial.

\section{DISCUSSION}

Active racehorse receives more training and exercises than retired horse, which implies more ROS would be produced in mitochondria and creates ROS overwhelming environment that might affect integrity of cellular macromolecules. However, antioxidant defence mechanism of younger horse are likely to be capable to diminish the adverse effect. In this study, the resultant DNA damage in peripheral cells between younger racehorses with more exercise and older retired horses with less exercise were compared. Laboratory investigation was repeated in 3 individual experiments. No statistically significant difference was observed in one of the trails only. The remaining two trials demonstrated active racehorses with lower baseline DNA damage and UVinduced DNA damage (Figure 1). Correlations between age and baseline and UV-induced DNA damage were investigated. Again, only one trial was not able to show significant positive association (Fig. 2).

It has been shown that significant intensive exercise in humans caused oxidative stress in leucocytes. Over exercising in humans could cause oxidation in peripheral blood mononuclear cell DNA [10]. However, positive results in terms of antioxidant capacity have been seen in some studies in youngsters. Human body is able to adapt and counteract the development of oxidative stress [11]. Our results in horses aligned with the observations in human [12] while slight deviation of observation with previous study in ponies. It has been shown the young ponies with lower endogenous DNA damage than mature and aged ponies while no difference in exogenous DNA damaged induced by hydrogen peroxide. There is no statistical significance association between different antioxidants, such as vitamin E, ascorbic acid, uric acid, iron and the lipid peroxidation marker malondialdehyde levels with DNA damage. However, a non-linear correlation between the red blood cell reduced glutathione and DNA damage is noted [13].

\section{ACKNOWLEDGMENT}

The author would like to thank $\mathrm{Mr} \mathrm{V} \mathrm{Lo} \mathrm{for} \mathrm{the}$ experimental work.

\section{REFERENCES}

[1] A. Azqueta, C. Ladeira C, L. Giovannelli, E. Boutet-Robinet. S. Bonassi, M. Neri, G. Gajski, S. Duthie, C. Del Bo', P. Riso, G. Koppen, N. Basaran N. A. Collins and P. Møller, "Application of the comet assay in human biomonitoring: an hCOMET perspective," Mutat Res Rev Mutat Res, vol. 783, pp. 108288, 2020.

[2] M. J. Jackson, A. Vasilaki and A. McArdle, "Cellular mechanisms underlying oxidative stress in human exercise," Free Rad Biol Med vol. 98, pp. 13-17, 2016.

[3] C. A. Williams, "The effect of oxidative stress during exercise in the horse," J Animal Sci, vol. 94, pp. 4067-4075, 2016.

[4] G. Marañón, B. Muñoz-Escassi, W. Manley, C. García, P. Cayado, S.M. de la Muela, B. Olábarri, R. León, E. Vara, "The effect of methyl sulphonyl methane supplementation on biomarkers of oxidative stress in sport horses following jumping exercise," Acta Vet Scand, vol. 50, pp. $45,2008$.

[5] H. E. Poulsen, "Oxidative DNA modifications," Exp Toxic Pathol, vol. 57, no. Suppl 1, pp. 161-169, 2005.

[6] J. Lykkesfeldt, O. Svendsen, "Oxidants and antioxidants in disease: Oxidative stress in farm animals," Vet J, vol. 173, pp. 502-511, 2007.

[7] C. M. Deaton, D.J. Marlin, "Exercise-associated oxidative stress," Clin Tech Equine Pract, vol. 2, pp. 278-291, 2003.

[8] Y. Minami, M. Kawai, T. C. Migita, A. Hiraga, H. Miyata, "Free radical formation after intensive exercise in thoroughbred skeletal muscles," J Equine Sci, vol. 22, pp. 21-28, 2011.

[9] S. Kinnunen, M. Atalay, S. Hyyppä, A. Lehmuskero, O. Hänninen, N. Oksala, "Effects of prolonged exercise on oxidative stress and antioxidant defense in endurance Horse," J Sport Sci Med, vol. 4, pp. 415-421, 2005.

[10] K. Tsai, T. G. Hsu, K. M. Hsu, H. Cheng, T. Y. Liu, C. F. Hsu, C. W. Kong, "Oxidative DNA damage in human peripheral leukocytes induced by massive aerobic exercise," Free Radic Biol Med, vol. 31, pp. 1465-1472, 2001.

[11] A. Avloniti, A. Chatzinikolaou, C. K. Deli, D. Vlachopoulos, L. Gracia-Marco, D. Leontsini, D. Draganidis, A.Z. Jamurtas, G. Mastorakos, I. G. Fatouros, "Exercise-induced oxidative stress 
responses in the pediatric population. Antioxidant (Basel)," vol. 6, pp. 6, 2014.

[12] V. Humphreys, R. M. Martin, B. Ratcliffe, S. Duthie, S. Wood, D. Gunnell, A. R. Collins, "Age-related increases in DNA repair and antioxidant protection: A comparison of the Boyd Orr Cohort of elderly subjects with a younger population sample," Age Ageing, vol. 6, pp. 521-526, 2007.

[13] D. J. Marlin, L. Johnson, D. A. Kingston, N.C. Smith, C. M. Deaton S. Mann, P. Heaton, F. Van Vugt, K. Saunders, J. Kydd, P. A. Harris, "Application of the comet assay for investigation of oxidative DNA damage in equine peripheral blood mononuclear cells," J Nutr, vol. 134, pp. 2133S-2140S, 2004. 